\title{
Urban Forests and Greening in the Republic of Serbia - Legal and Institutional Aspects
}

Nenad Lukić

University of Novi Sad, Faculty of Agriculture Novi Sad, Serbia

\section{Abstract}

Background and Purpose: This research attempted to answer some general questions about the legal and institutional support for urban forests and greening in Serbia by focusing on the important aspect of urban forests and greening from the perspective of social sciences. It was interesting to reveal which institutions are in charge of these areas and who claims to have responsibility for their management and protection. This research was expected to contribute to the better understanding of the status of urban forests and greening in Serbia today.

Materials and Methods: Document analysis and face-toface interviews were applied as methods of collecting relevant empirical data in order to discover if any, and which legal documents were addressing urban forests and greening in Serbia.

Results and Conclusions: The term "urban forests" is not generally accepted by domestic practice and among professionals who work in this or related fields. Instead, terms like peri-urban forests and park-forests are used in Serbia. The Serbian law does not recognize this term and states that forest may not be areas smaller than 5 ha. Because of the difficult period Serbia has endured in the last 20 years (wars, UN sanctions, the economic crisis) the overall care for urban greenery has fallen into background and is no longer an important topic among the politicians and the general public. In the last few years we have noticed some positive improvements like the adoption of new, more adequate laws, reviving of institutions that affect this field etc.

Keywords: urban forests, urban greening, legislation and institutions, Republic of Serbia

\section{INTRODUCTION}

Green areas in cities are considered integrated parts of every larger settlement and absolutely required for the life quality of its citizens. Cities without this element are considered extremely inadequate for living. We may say that residents have literally been fleeing the parts of cities where green elements are missing, as if these spaces had turned "sick". The greenery in urban areas offers multiple benefits. Plants, especially trees and shrubs, with their forms, structures and life features, are irreplaceable natural elements in cities that contribute to the melioration of the environment in the broadest sense of the word [1]. The importance of urban greening may best be described with the idea of "garden cities" presented to the public by the English architect Ebenezer Howard in late $19^{\text {th }}$ century. This idea, although sometimes considered as utopia, represented the attitude that the greenery and the presence of plants in urban areas, create the only environment framework enabling humans a dignified life [2].

When we speak about urban forests, there are several definitions. The term may be described as the space dominated by high woody vegetation accessible to city residents by foot, bicycle or public transportation, having a primary social and ecological purpose [3]. Urban forestry is the management of planted and naturally occurring trees in urban and urban-interfaced areas [3] and, also, the art, science and technology of managing trees and forest resources in and around urban community ecosystems for the physiological, sociological, economic and aesthetic benefits to the society provided by trees [4].

While forestry is expected to be, in most cases, an income generating activity and to provide existence for some people, we do not expect landscape architecture and city green spaces to produce economic income [1], at least not directly. Nevertheless, should we 


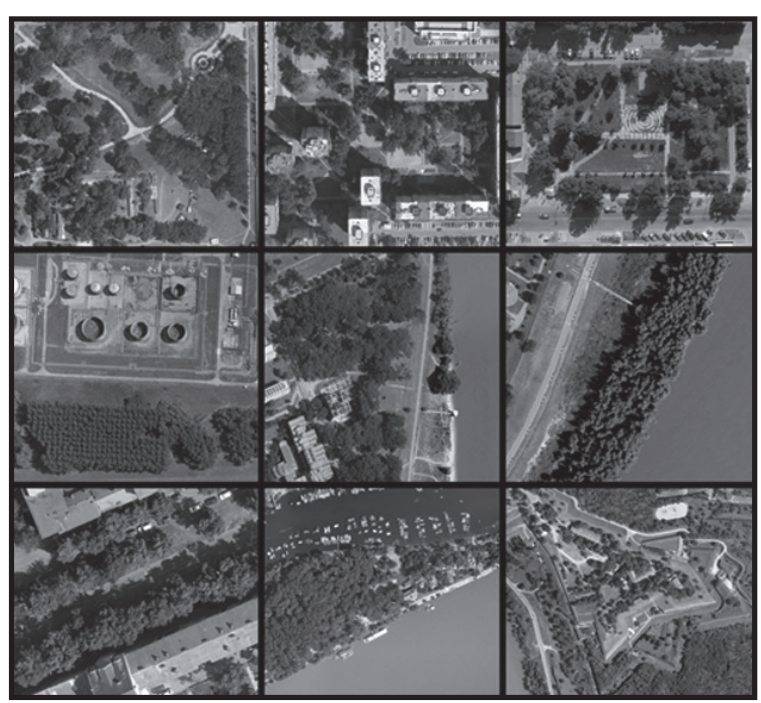

FIGURE 1

Various types of urban greenery in the City of Novi Sad, Serbia (source: www.geosrbija.rs)

realize that a well-organized and developed green infrastructure raised the income of tourism, decreased health problems and increased work enthusiasm and productivity among citizens, we might say that green spaces were, in general, highly profitable.

Several different elements significantly affect urban forests and city greenery. Some of them are financial support, the awareness of the importance of urban forests and greenery, the development level of professionals who work in this field and, lastly, but not less important - legal and institutional aspects, that is, the legal support this subject should receive from the society. Adequate laws and other types of legislature are important, but also, this legislature should be respected and implemented in the field, as well as in everyday life. The latter is a task for public institutions on different authority levels. Serbia has three authority levels (national, provincial and local) so it is important we understood the functioning of the political mechanisms in this field and to establish a better collaboration among institutions.

The main aim of this research was to find out the state of urban forests and greening in the Republic of Serbia from legal and institutional aspects, as well as to reveal whether the term "urban forests" existed in Serbian legislature and whether it is used by the professionals working in this field. It was interesting to reveal which institutions are in charge in these areas and who claims to have responsibility for their management and protection. The research was expected to contribute to the better understanding of the status of urban forests and greening in Serbia today.

\section{MATERIALS AND METHODS}

This research was done by two different methods: (I) document analysis and (II) face-to-face interviews.

\section{Document analysis}

The main source of information for the document analysis was based on a large database of valid Serbian laws $[5,6,7]$, spatial and urban plans [6], national and local strategies $[8,9]$, decisions [10], statutes, local greenery regulations [11], action plans, studies [12], publications [13], national programs and inventories $[14,15]$, as well as drafted laws [16] that are to be enacted in the near future and similar documents that influence or will affext urban forests and city greening in the Republic of Serbia. During this period (February 2012 - August 2012) the author studied more than 50 different official documents, but the majority carry no reference to urban forests and greening which implies that this subject is not represented well in domestic documents and legislative. All three levels of authority with the right to pass legislature were taken into account - national, provincial and local, in order to achieve a broader picture of the current state of this field.

\section{Face-to-face interviews}

The second research method were visits to all relevant institutions working and influencing urban forests and greening. Face-to-face interviews were applied as a method to obtain adequate information on this topic. During the research period (May 2012 - July 2012), 10 institutions, located in the City of Novi Sad, Serbia, were visited and of their employees' answers recorded. The visited institutions were: one institute (for lowland forestry and environment), four public companies (for city greening, urbanism, forests and city development), two city administration offices (for environment and communal activities), two province secretariats (for urbanism and protection of nature) and one non-governmental organization (NGO). One employee was interviewed in each institution. The criteria for the selection were that the employee was in charge of business related to urban forests and greening within the institution and had a high education background (university level) in the related field. All were asked the same, open type questions about the responsibilities in this area: the compliance to the laws; the applicability of current laws, etc.

\section{RESULTS AND DISCUSSION}

\section{Document analysis}

In general, urban and peri-urban forestry and greenery has been receiving little attention on political agendas despite its importance to the society in terms 
of the social, economic, aesthetic and environmental benefits. This is even more problematic in developing countries and countries with economies in transition, where urban development is too often accompanied by the severe degradation of the environment (including trees and forests), increased poverty and food scarceness. Good tree and forest management in and around cities, combined with good governance, appropriate policies, participatory approaches and the capacity building of stakeholders should lead to convincing and promising results [17].

In Serbia, city greening has developed in five different historical periods. The first was during the medieval Serbian state when organized greening was done in and around monasteries and castles, parts of that greening being gardens with medicinal herbs, fruit and vegetable gardens and monastery forests. The second period was during the Ottoman Empire occupation when private gardens surrounded with high walls were presented as intimate family spaces. Public greening was reduced to cemeteries, mosque yards and around an occasional public buildings. During the third period and the renewal of the Serbian state, settlements were planned in orthogonal order, many public buildings surrounded with greenery, while some markets become parks or squares as alleyways appeared along important city streets. In the period between the two World Wars (the fourth period), the building of parks intensified, especially in the capital city of Belgrade, and most of them still exist today. The fifth period was marked with efforts to deal with the city greenery according to modern conceptions. The principal problems for further development in this area were limited space possibilities in highly populated areas. The remaining free land in the cities become too expensive and priority was not given to greenery. The current greenery city system was not built in an organized way so its sanitary and hygienic effect is not satisfactory [18].

Urban forests may be seen as a link between classic forests and urban greenery, but this research reveals that the term "urban forest" is not generally accepted in the domestic professional community, as well as in Serbian literature and legislation. Mentioning urban forests in the institutions that deal with this and the related fields, showed the understanding of the concept and its acceptance as relevant only in rare cases. This implies that it would take some time for this concept to be accepted and adopted in the domiciliary practice. The best proof thereof are the few laws, such as the Forest Law [5]: "A forest, under this Act, means the area of land larger than 5 acres covered with forest trees. The term forests does not include separate groups of trees in an area of less than 5 acres, trees in urban parks, and trees beneath the power supply lines". This legislation also emphasizes that the purpose of forests is not just the production but it is also a place where citizens have free access the purpose of enjoyment, relaxation and recreation, with a personal responsibility for their own safety and the obligation not to devastate the forest. This law implies that managing forests as a natural resource is under the jurisdiction of the Republic of Serbia and under the governance of the Ministries, the governing body of the autonomous province on its territory, and all legal entities for forest management for the stateowned entities and state forests owners [5].

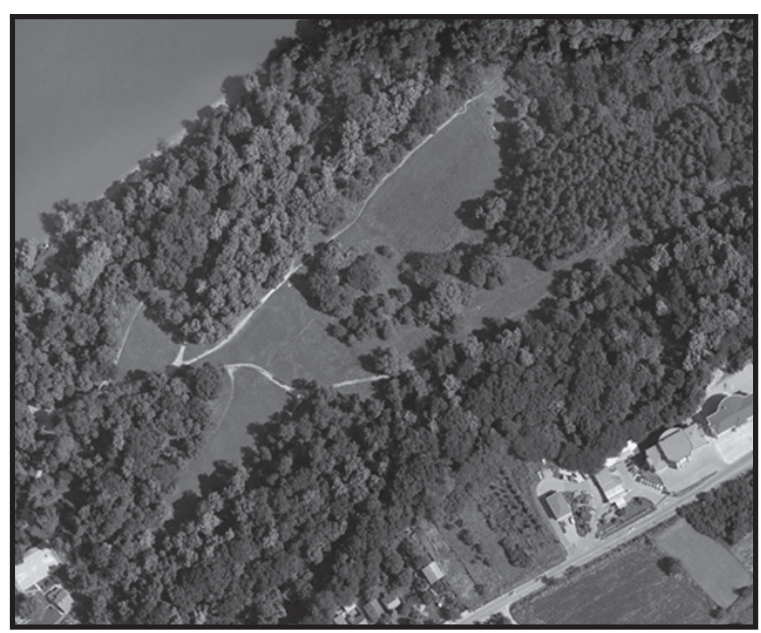

FIGURE 2

An urban forest, Novi Sad, Serbia (source: www. geosrbija.rs)

When we deal with the protection of urban forests, it is important to know that "The conservation of biological diversity of forest ecosystems is implemented to strengthen the overall useful function of forests" [19] which includes social functions. The first reference to the protection of forest areas originates from the $14^{\text {th }}$ century and the King's Dušan Code - the first official law in Serbia, stating that the significance of forest protection had been realized very early [13]. Some other documents implied that primary education and the mass media do not provide enough information about the importance of forests, forestry and their benefits to people and the general development of Serbia. Also that this deficiency shows in the undeveloped environmental awareness of our citizens that often manifests itself in a variety of negative aspects, especially in relation to forestry activities [8]. Under various legal provisions, whole or parts of urban forests and urban green spaces may be protected as the natural and cultural heritage important for the city or state [12], the fact that may significantly improve the condition and the longevity of some important green areas. 
In 2005, the Government adopted the National Strategy of the Republic of Serbia to join the European Union. Since 2004, intensive projects have been done on the harmonization of domestic legislation with the legislation of EU [6]. One of the major problems is the financing of environmental protection, which also includes urban forests and greening. The strategy of biodiversity implies that the sources of financing the environmental protection in the Republic of Serbia, including the funds from the national budget, shall be allocated across ministries, institutions and special purpose funds, as well as the budgets of local governments, so that financial means should be provided by a number of bilateral and multilateral agreements. Major international funds are certainly pre-accession EU funds [9]. A source for funding may be also found in the income from the penalties for inappropriate treatment of trees and city green spaces. In a few other laws we may find strict fines, such as: "a fine of $500 €$ to $5000 €$ for a legal entity in case of the violation of green spaces and a fine of $200 €$ to $500 €$ for individual persons in case of the same violation" [7]. One draft law, soon to be passed, regulates that "every person or a legal entity shall be charged a fee of $2000 €$ if a tree is cut without the permission of local authorities" [16]. Currently, in Serbian cities citizens are paying for communal services co-financed by the state and city budgets which is an aggravating circumstance. Public utilities should be financially supported by applying the principles of the full cost recovery for environmental services [14] in order to improve the maintenance and the current condition of urban forests and city greenery.

Forests cover $30.7 \%$ of the Republic of Serbia [15]. In comparison, this percentage is closer to the global coverage of $30 \%$, and much lower than in the EU, which is $46 \%$ [15]. Also, rare cities have an adequate percentage of green spaces (15- $25 \mathrm{~m}^{2} / 1$ city resident) [12] and even less have urban forests of good quality, providing a pleasant stay and being accessible to common people on foot, by a bicycle or public transport. The last two decades have witnessed the loss of green and open spaces in urban areas and the vulnerability of public spaces. Many cities are changing the purpose of such spaces, where parks, public and green spaces are recognized as new "spatial options" for construction. This reduces the ecological quality of the existing environment and creates an imbalance which threatens the sustainability of cities. The rules of construction and changing the purpose of urban spaces are currently defined primarily by the interests of investors and only then by the interests of citizens and the public. In this way, the cities in the Republic of Serbia lose the quality of the urban structure [6]. On the local level - through local plans, projects and initiatives cities and other urban areas undertake the obligation to limit the spreading of urban/suburban areas and provide an absolute protection of green and open urban spaces [6]. Protecting and improving green spaces should be done by municipal authorities, legal entities, individuals and enterprises, institutions and other professional organizations involved in the planning, implementation, design, construction, supervision and maintenance of green areas on territories of local self-governments [16].

Users and citizens are also responsible for the state of urban forests and greenery, therefore also required: (a) to use public green spaces according to their main purpose; (b) to send a written notice to the public company responsible for city greening, that a tree or other vegetation poses a danger to life, health or property; (c) to maintain special-purpose communal gardens and greenery; $(d)$ to obtain a consent from the appropriate public company prior to planting vegetation and later to maintain the planted vegetation [10]. It is important to emphasize that public spaces and personal engagement is a contemporary trend of greening big cities where the motivation is to envolve the users in the process of planning, construction, maintenance and the conscientious use of green spaces [12].

Lately, the professionals working in this domain have become aware of the usefulness of GIS systems, because the GIS of green spaces for a large number of European and world cities is a key part of an information base, a modern tool for a more efficient and cost-effective maintenance of the existing and the planning of new green spaces [11]. Spatial and urban plans and projects on local levels are very effective and powerful tools in the field of urban forests and greening. We may say that there are significant improvements in this area because of a considerable increase of referring to forests and greening in such plans. A good example is the Spatial Plan for the City of Novi Sad, where the concept of forests and forest land development within the plan means increasing forest areas, improving the existing forests and their use in accordance with the principles of environmental protection, as well as realizing their cultural, social and production functions.

\section{Face-to-face interviews}

The main results of the research interviews are that the interviewed professionals currently do not accept the term "urban forests" and the reference to it causes doubts. A public company responsible for urban greening does not take care of urban forests surrounding Novi Sad and these forests are under the jurisdiction of the public company responsible for the forests in the province of Vojvodina. This implies that these forests are not seen as parts of the city greenery, they are not linked enough with the city greenery system and the residents do not visit them often. 
The interviewed professionals quote the main problem of urban greenery to be the lack of funds, the lack of moisture in the soil and the lack of city irrigation systems, political interference in profession matters, the lack of a targeted production of planting material that must be compensated by the import of seedlings from far away countries with different climates, the absence of legislation (law, strategies) that would clearly define urban forests and greening, the excessive paving of the city, etc.

\section{CONCLUSION}

Urban forests and greening have fallen into background, because of the economic crisis that has lasted for over 20 years, several wars and UN sanctions in the 90 s, as well as the overall lack of care for the environment. This was also not an important topic among the politicians and in public, since people were preoccupied with existential problems. The situation is not different even today, but now we are noticing some positive improvements in this field reflected in the adoption of new, more adequate laws, in greater financial investments and the gradual spreading of environmental awareness of people who are beginning to realize that a healthy environment is extremely important for our quality of life and that urban forests and greening are one of the most important factors of that environment. It is surprising how this issue affects so many different institutions and sometimes even professionals who are in charge in this field, nevertheless not completely certain exactly which institution is responsible for what. This should be changed and maybe this research will contribute to the better understanding of the status of urban forests and greening in Serbia, as well as in the other countries that have similar situation.

\section{Acknowledgment}

This research was realized in coopearation with Institute of Lowland Forestry and Environment, Novi Sad.

\section{REFERENCES}

1. ANASTASIJEVIĆ N 2002 Establishment and Maintenance of Green Spaces, Faculty of Forestry, Belgrade, p 37

2. VRATUŠA V 2005 Urban Ecology, Faculty of Forestry, Belgrade, $\mathrm{p} 82$

3. MILLER R W 1997 Urban Forestry: Planning and Managing Urban Green Spaces, $2^{\text {nd }}$ edition, Prentice-Hall, New Jersey

4. HELMS J A 1998 The Dictionary of Forestry, Society of American Foresters, Bethesda

5. THE MINISTRY OF AGRICULTURE, FORESTRY AND WATER MANAGEMENT 2010 Forestry Law, Official Gazette, Republic of Serbia

6. THE MINISTRY OF NATURAL RESOURCES, MINING AND SPATIAL PLANNING Law on Spatial Planning of the Republic of Serbia since 2010 to 2020, Official Gazette, Republic of Serbia

7. THE MINISTRY OF ENVIRONMENT, MINING AND SPATIAL PLANNING 1988 Law on Communal Activities, Official Gazette, Republic of Serbia

8. THE MINISTRY OF AGRICULTURE, FORESTRY AND WATER MANAGEMENT Forestry Development Strategy of the Republic of Serbia

9. THE MINISTRY OF ENVIRONMENT AND SPATIAL PLANNING 2011 Biodiversity Strategy of the Republic of Serbia for the period 2011-2018
10. THE CITY OF NOVI SAD 2011 Decision of arrangement, maintenance and protection of green areas and public beaches in City of Novi Sad, Official Gazette of Novi Sad City

11. THE CITY OF BELGRADE 2003 Belgrade Green Regulative, Public Company for Urbanism, Belgrade

12. FACULTY OF AGRICULTURE, UNIVERSITY OF NOVI SAD 2009 Study of Green and Recreational Area of Novi Sad City, Novi Sad

13. THE MINISTRY OF AGRICULTURE, FORESTRY AND WATER MANAGEMENT 2008 Publication "Beautiful forests of Serbia"

14. National Environment Protection Program, Republic of Serbia, 2010

15. BANKOVIĆ S, MEDAREVIĆ M, PANTIĆ D, PETROVIĆ N 2006 National Forest Inventory of the Republic of Serbia

16. The Draft Law on the Protection and Promotion of Green Spaces, Republic of Serbia

17. KNUTH L 2005 Legal and institutional aspects of urban and peri-urban forestry and greening, FAO, Rome, $p$ 7,11

18. VUJKOVIĆ \} 2 0 0 3 \text { Landscape Architecture: Planning and } Designing, Faculty of Forestry, Belgrade, pp 23-25

19. MINISTRY OF ENERGETICS, DEVELOPMENT AND NATURE PROTECTION 2010 The Law on the Protection of Nature, Official Gazzete, Republic of Serbia 
